\title{
NON-INDIGENOUS PARASITES OF FISH IN INLAND WATERS OF CROATIA
}

\section{Matija Pofuk}

Ministry of Agriculture, Directorate of Fisheries, Ulica grada Vukovara 78, 10000 Zagreb, Croatia

*Corresponding Author: matija.pofuk@mps.hr

\section{ARTICLE INFO}

Received: 13 April 2021

Accepted: 7 July 2021

\section{ABSTRACT}

Non-indigenous parasite fauna of freshwater fish has not been studied extensively in Croatia, despite the long history of introductions and translocations of alien fish species into inland waters. Negative implications for aquaculture production and wild native fish species have been frequently associated with the introduction of non-native parasite species. Hence, the present paper attempts to lay out a historical overview of the suspected localities, time frames and pathways of introduction for nonindigenous fish parasites into inland waters of Croatia, therefore producing a list of species. In total, 16 non-native fish parasites have been recorded in inland waters of Croatia, aquaculture establishments being identified as initial points of introduction. However, a paucity of information exists on the overall prevalence of infection as well as the economic impact on aquaculture production. In addition, limited information is available about the presence and potential ecological impact of non-indigenous parasites on endemic fish fauna in areas of high biodiversity, such as the water bodies of the Adriatic Sea Basin. Therefore, there is an urgent need and opportunity for multidisciplinary cooperation between different stakeholders, including government, scientists, in both biological and veterinary disciplines, and the industry, with the aim of extensive surveys to determine the potential impact on aquaculture production and wild fish population of high conservation value.

Pofuk, M. (2021): Non-indigenous parasites of fish in inland waters of Croatia. Croatian Journal of Fisheries, 79, 187-204. DOI: 10.2478/cjf-20210020. 


\section{INTRODUCTION}

Biological invasions present a serious threat to the environment, economy and public health on both local and global scales. These phenomena have caused an unprecedented impact on the bio-integrity of native biodiversity, causing loss of and/or shifts in fundamental ecosystem functions and the corresponding provision of goods and services (Vitousek et al., 1997; Simberloff and von Holle, 1999; Rahel, 2000; Kolar and Lodge, 2001; Prenter et al., 2004; Keesing et al., 2010; Cardinale et al., 2012). Human global travel and commerce, expanding agriculture, and associating introductions and translocations of animals to new geographic areas have triggered the emergence of infectious diseases (EIDs) of domesticated animals and wildlife, which may cause disastrous depopulation of (immunologically) naïve host populations, followed by chronic population depression and, in some cases, local extinction, thereby causing loss of biodiversity (Daszak et al., 2000). Some examples of EIDs (e.g. Varroasis, crayfish plague) have already seriously impacted native species populations of significant conservation values. Biological invasions and EIDs are not necessarily independent from each other and together they could impose additive or synergistic impacts on ecosystems (Poulin et al., 2011). Native freshwater environments and ecosystems are especially susceptible and vulnerable to biological invasions and to the dissemination of micro- and macroparasites, which are easily transmitted between wild and cultured fish species living in close sympatry with each other. Interaction and transmission of infectious diseases between the sympatric reservoir and susceptible populations of domesticated animals and wildlife are defined as spill-over (Daszak et al., 2000), whereas the term spill-back refers to the acquirement of native parasites by competent invasive host species, which are then able to disseminate the infective stages of parasites back to a native species (Kelly et al., 2009). A literature review by Lymbery et al. (2014) based on 98 published studies identified alien (non-indigenous) fish as the most common hosts for the introduction of non-indigenous parasites (NIPs) across a broad range of taxa, including mammals, birds, amphibians, insects, crustaceans and molluscs, making up $55 \%$ of the total transfers. Indeed, concerns have been raised over the impact of NIPs on endangered native fish species in Europe, with implications for population declines, therefore representing a significant threat to biodiversity (Gozlan et al., 2005). Although trans-oceanic trade in exotic ornamental aquatic species has a longstanding history from at least the early $17^{\text {th }}$ century (Balon, 2004; Novák et al., 2020), it was in the $20^{\text {th }}$ century that globalisation and technological breakthroughs in modes of transportation (i.e. air travel) facilitated the acceleration of international movement of fish, but also other exotic aquatic species, thereby establishing a significant pathway of spreading EIDs of aquatic wildlife and cultured aquatic animals (Alderman, 1996; Hedrick, 1996; Peeler et al., 2011). Parasitic organisms have an important function in ecological systems. As frequent and essential elements of biological communities, parasites have a role in the control of host populations and the structure of ecological communities, thereby providing a pest control service (Torchin and Mitchell, 2004). They can form the dynamics of host populations and communities, change competition strength and affect trophic relationships and drive biodiversity (Britton, 2013), as well as have a fundamental role in determining the success of a biological invasion by the impact on host fitness and by shifting interactions between native and non-native host species (Dunn, 2009). NIPs may have an adverse ecological impact on the level of individuals (immunity function), populations (genetic diversity), ecosystems (function and services) as well as human health (zoonotic parasites) (Daszak et al., 2000). They have been implicated to impact survival, fecundity, physiology and behaviour of host species (Prenter et al., 2004), as well as population dynamics of wildlife causing temporary or permanent declines, and shifts of patterns of food web topology and food web stability (Thompson et al., 2010). NIPs may negatively influence the host species phenotype by altering their foraging behaviour, feeding rates, competitive relationships as well as modification in their life-history traits, including growth rates and reproduction (Britton, 2013). In addition, sublethal infections can induce pathological, physiological and behavioural changes, and consequently negatively impact growth, fitness and survival (Britton, 2013). In captive conditions (i.e. aquaculture, aquariums), apart from direct losses to the cultured stock induced by mortality, parasites may have a significant impact on growth rate and feed conversion ratios, reproductive fitness and behaviour of fish, susceptibility to other infections and resistance to stress agents, susceptibility to predation as well as marketability of fish (Scholz, 1999; Tavares-Dias and Martins, 2017; Faruk, 2018). Globally, NIPs cause enormous economic losses to fishery and aquaculture industries. Parasite infections may impact aquaculture production as direct losses (productivity, loss of stock) and indirect costs such as control, prophylactic treatment and management, cost of culling, and those associated with secondary infections, loss of trade and reputation as well as rippling socio-economic effect on supporting secondary and tertiary industries and markets, shifts in price with reduced supply, loss of employment, livelihoods and vital protein source and foreign exchange (Oidtmann et al., 2013; Peeler et al., 2015; Shinn et al., 2015a; Sim-Smith and Diggles, 2019). Furthermore, the disease has been recognised as the major limiting factor for the expansion of aquaculture production and thereby to global food security in the future (Stentiford et al., 2012, 2017). At present, decision and policy planners and makers in the administration and management of fisheries and aquaculture have standardised guidelines, recommendations, rules and regulations at their disposal 
(e.g. Aquatic Animal Health Code by OIE, EU regulations) which set out veterinary inspection, surveillance programs, importation quarantine measures and methods (see Molnár et al., 2019). However, despite tight trade measures, and established customs and quarantine methods and protocols related to transboundary aquatic diseases in the many Member States of the European Union, introductions of NIPs into aquaculture are still occurring, routes of transfer being illegal and uncontrolled live aquatic animal movements, parathenic animals (sub-clinical carriers), non-live aquatic product or weak enforcement of import trade measures (Gozlan et al., 2006; Whittington and Chong, 2007; Oidtmann et al., 2013). National and international institutions and programs that manage the health of aquaculture animals have been primarily focused on listed diseases of supranational relevance, while the strategies for the prevention of non-listed diseases from Low-Income Food Deficit Countries (LIFDCs), where the majority of the present and future production is located, have been less effective, and together with reactive and slow responses by the scientific and governmental institutions, often accelerated the introduction events during trade (Stentiford et al., 2017).

NIP fauna of freshwater fish has not been studied extensively despite a long history of intentional (and unintentional) introductions and translocations of alien fish species in inland waters of Croatia (Piria et al., 2017; Pofuk et al., 2017; Ćaleta et al., 2019; Mihinjač et al., 2019). A detailed review, particularly species composition, origin, distribution and mode(s) of introduction, as well as the potential impact that they might have on native fish species in open water and on aquaculture production, is therefore required. Hence, the present paper aims to review available domestic literature published by veterinarians, specialised in fish disease and parasitology, as well as other aquatic health specialists referring to parasite infections in freshwater fish either under aquaculture conditions or inland waters, and crossreference the identified species list with internationally published records of NIP introductions. The objectives are to identify: a) exotic fish parasite species composition in open waters and aquaculture conditions of Croatia; b) their geographical origin; c) pathways of introduction; d) status; e) potential impact on native fish fauna; and f) economic significance to Croatian aquaculture production.

\section{DATA COMPILATION, METHODS AND TERMI- NOLOGY}

Data compilation was carried out to produce: i) a record of known introductions of NIPs of freshwater fish into inland waters of continental Europe, with special reference to watersheds of the Danube River Basin (i.e. Central and Eastern Europe); and ii) a dataset of proven ecological and economic impacts of non-native parasites on native fish fauna and freshwater aquaculture, respectively. These data were then cross-referenced with Croatian records to compile iii) a register of NIPs in inland waters of Croatia; and iv) status and recorded ecological and economic effect on native species in open waters and aquaculture conditions. Two sources of available literature were used for the investigation. Printed (books, chapters in books) and digitalised (scientific and professional papers) materials were obtained from the: 1) National and University Library in Zagreb, 2) Library of the Department for Biology and Pathology of Fish and Bees, Faculty of Veterinary Medicine, University of Zagreb, 3) central portal of Croatian scientific journals HRČAK (https://hrcak.srce.hr/?lang=en) and 4) Croatian Scientific Bibliography CROSBI (https://www.bib.irb.hr). The second sources were electronic search engines and digital libraries, such as PubMed (https://pubmed.ncbi. nlm.nih.gov/) and Google Books (https://books.google. $\mathrm{com} /$ ), which were surveyed for internationally published monographs, technical reports, symposium papers and compendiums of parasitological literature such as the Index-Catalogue of Medical and Veterinary Zoology from the U.S. Department of Agriculture as well as bibliography reviews or other primary sources (e.g. McGregor, 1963). In addition, web search engine Google Scholar was used, using keywords "freshwater fish", "non-indigenous/ exotic/alien", "parasite", "record", "introduction/ translocation", "vector" "pathway" "spread", "invasion" "infection", "effect" "impact". Although there are many forms of parasitism in nature incorporating numerous organisms, for practical purposes, only species in protozoa and metazoa are considered true parasites (Molnár et al., 2019). Therefore, the focus was directed towards the most ecologically and economically important protozoan and metazoan parasites in aquaculture conditions and open waters, such as ciliates, myxosporeans, parasitic worms (helminths: monogeneans, cestodes, digeneans) and copepodite crustaceans (Hoffman, 1999) as well as pathogens with a complex evolutionary history, like the Class Mesomycetozoea (orders Dermocystida and Ichthyophonida), a monophyletic group of protists, placed near the point of animal-fungal divergence (Rowley et al., 2013).

\section{Determination and origins of non-native parasites}

Determining whether a fish parasite is native or non-native in inland waters of Croatia is a challenging task due to the paucity of research in fish parasitology up until the second part of the $20^{\text {th }}$ century (Mršić, 1934-1935; Babić, 1935), as well as due to few taxonomical surveys and publicized or documented events describing pathways of NIP introductions, and subsequent dispersal (Tomašec, 1953a, b, 1966, 1967; Fijan, 1971, 1974, 1978, 1982, 2006; Ivassik and Kulakovska, 1968). Up until the 1950s, fish health services for freshwater aquaculture in Central and Eastern Europe were established based on the work by German specialists from whom the knowledge was transferred 
to other regions of Europe, whereas a discipline of fish health science (fish parasitology) was predominated by Soviet, Czech and Polish experts (Molnár et al., 2019). Extensive research and publications by authors from these regions became the backbone of modern fish pathology and parasitology. Therefore, the parasite zoogeography was determined by cross-checking international (Lom and Hoffman, 1964; Hoffman, 1970; Hoffman and Schubert, 1984; Bauer and Hoffman, 1976; Molnár, 1984a; TrujilloGonzales et al., 2018) as well as regional (Kulakovskaya and Ivasik, 1967; Ivasik and Kulakovska, 1968; Musselius, 1969; Molnár, 1979, 1984b; Bauer, 1979; Dyková and Lom, 1988; Kirjušina and Vismanis, 2007) records of NIP introductions with the published work of national specialists. It is particularly difficult to ascertain the origins of parasites that are ubiquitous in geographical distribution, highly cryptic or have ambiguous taxonomies because parasitological investigations in taxonomy as well as monitoring programs started long after global dissemination of NIPs by anthropogenic activities such as international trade of live fish (Taraschewski, 2006; Lymbery et al., 2014; Trujillo-Gonzales et al., 2018). Ciliate Ichthyophthirius multifiliis Fouquet 1876, which causes ichthyophthiriosis ("ich", "white spot disease"), is a prime example due to cosmopolitan distribution and globally reported infections of numerous species of fish in freshwater systems. Although the first comprehensive description of the organism dates back to the late $19^{\text {th }}$ century (Stiles, 1894), the disease was already known for centuries from aquariums and large estate fish ponds in Europe (Buschkiel, 1937), and has presumably originated from ornamental cyprinids [i.e. goldfish Carassius auratus (Linnaeus 1758)] imported from Asia (Nigrelli et al., 1976; Hoffman and Schubert, 1984; Matthews, 2005), as was the case in subsequent reports from other continents (Paperna, 1991; Dickerson, 2006; Trujillo-Gonzales et al., 2018). The earliest record of the specific "white spot disease" or "fish louse" in fish skin is referenced in the work Interrelationships of organisms by the author Sushih during China's Sung Dynasty (A.D. 960-1279) (Dashu and Lien-Siang, 1960), interestingly the time and area where goldfish has been kept in domestication (Balon, 2004). Unfortunately, as the parasite became established worldwide early on and rapidly, the pathways of introduction and subsequent invasion became impossible to document, thus the true origin of this parasite will probably never be resolved (Taraschewski, 2006). However, in this review, the organism will be tentatively listed as a non-indigenous parasite (see below).

\section{Identification of pathways, dates and status of non- native parasites introduction}

Invasive fish parasites raise concerns on global as well as regional levels because, in case of establishment in a particular area of the initial introduction, subsequent transmission and spread of the parasite may transcend political and biogeographical borders. Moreover, when an NIP becomes established, control or eradication programs are largely ineffective (Oidtmann et al., 2011). Establishing the pathways and routes of initial transfer may be useful to identify and predict the subsequent process of colonisation as well as further range expansion; moreover, the shared hydrologic network between Central and Eastern Europe may amplify the invasion potential of non-indigenous parasites. Indeed, identification of pathways of introductions may have a pivotal role in determining the function of species and ecosystem traits in biological invasions and for anticipating future trends as well as for the development of preventive methods, including systems of screening and interception, early warning strategies and import regulations (Hulme et al., 2008). It is well documented that, in addition to freeliving organisms, non-indigenous parasites may overcome large (i.e. intercontinental, transcontinental) or small (i.e. regionally adjacent water systems or fish farms, between ponds of a fish farm) geographical scales (Musselius, 1969; Hoffman, 1970; Molnár, 1984a). The introduction of an alien species into a novel geographical area, as a direct or indirect result of anthropogenic involvement, is manifested through three wide mechanisms. These are the importation of a commodity, arrival of a transport vector and/or natural spread from a neighbouring region in which the species is alien. These result in six fundamental pathways, namely release, escape, contaminant, stowaway, corridor and unaided (Hulme et al., 2008). Fish parasites are closely associated with unintentional arrival as a contaminant of a commodity (live or products), a stowaway in a transport vector and natural spread through neighbouring waterways, either with the native host species or non-native vector species (Oidtmann et al., 2011). In a practical sense, NIPs may be introduced by direct or indirect transfers. The former includes human activities such as stocking of fish (food, sport, ornament) and the use of fish as live bait, whereas the latter occurs via ballast water, aquaculture transport vehicles, ships' hulls, floating weeds and fouled mobile surfaces, the release of pets or excess stock, range expansion of wild fish host populations, infested water (viable life stages), entanglement in fishery equipment and gear, predators (birds) or by native species which have been translocated, infected and then re-introduced into their original area of distribution (Holdich and Pöckl, 2007; Hulme et al., 2008; Lymbery et al., 2014; Boonthai et al., 2017; Trujillo-Gonzales et al., 2018).

Determining the correct date of introduction and/or initial source of infection in a geographical area has historical significance as it enables a reliable track of events that led to the establishment and spread of a novel parasite, as well as it provides a baseline for the estimation of potential economic and ecologic impact in subsequent time frames. In the absence of historical records, linking parasites to specific host species introduction events is impossible (Trujillo-Gonzales et al., 2018), therefore, establishing time and place of parasite emergence 
may possibly be advantageous as it could help mitigate the invasion of the parasite and potentiate eradication programs before transfer to other localities. Indeed, following the first detection, the essential step to contain further range expansion of the parasite is to establish the geographical route of parasite spread (Oidtmann et al., 2011). However, non-indigenous parasites may be observed only after their presence becomes evident, which may take months to years following arrival and may involve a natural spread from a separate waterbody (Minchin, 2007). In order to be considered a threat to native hosts in the introduced range, NIPs must overcome equal barriers to introduction, establishment and invasion as free-living aliens as well as be able to host switch from alien to native species (Lymbery et al., 2014). However, the establishment and invasion process and success of NIPs is dependant on several biological and ecological factors. These include the presence of susceptible (intermediate and final) host, age of the host and host resilience, host genetic diversity, threshold host density for parasites with density-dependent transmission, intensity of introductions (repeated or secondary introductions) of the host population, accessibility of free niches for their hosts, complexity of the parasite life cycle (monoxenous: singlehost or heteroxenous: multiple-host), recipient and source region, and their host fauna similarity, environmental conditions and, more recently, climate change (Bauer, 1991; Torchin and Mitchell, 2004; Gozlan et al., 2006; Galli et a., 2007; Dunn, 2009; Altizer et al., 2011; Poulin et al., 2011; Britton, 2013; Lymbery et al., 2014; Médoc et al., 2017; Stuart et al., 2020). In addition, during the invasion process, NIPs, which are generally derived from small subsets of populations with occasionally uninfected life stages, are "filtered out" in the new environment, therefore inhibiting the probability of introduction and establishment with their host species (Torchin et al., 2003; Torchin and Mitchell, 2004). Lymbery et al. (2014) pointed to the frequency of cases of alien parasites with indirect life cycle establishing in new areas of introduction as well as to the lack of evidence of the impact of the life cycle complexity on host switching. They proposed the implementation of the terminology co-introduction and co-invasion to define the status of NIPs, noting that the difference between introduction and establishment is of low utility, as in many cases introduced parasites that do not establish are not likely to be ever recorded (Lymbery et al., 2014). For practical purposes, these terms will be used to infer the status of alien parasites in this review. The nomenclature and classification of fish host species (i.e. scientific and common names) follow FishBase (Froese and Pauly, 2020).

\section{RESULTS}

\section{Non-indigenous parasites and geographical origins}

A total of 16 exotic species of parasites have been recorded in captive conditions (i.e. aquaculture and aquariums), of which at least six in open waters of Croatia up to the present (Table 1). NIPs are represented by species belonging to 7 taxonomic groups: Ciliophora (1), Myxozoa (3), Mesomycetozoea (2), Platyhelminthes (Monogenea 4; Digenea - 1; Cestoidea - 3) and Arthtopoda (Copepoda -2). The majority of NIPs (14) recorded in Croatia are of Asian origin, whereas two others, the Mesomycetozoean Ichthyophonus hoferi Plehn \& Mulsow 1911 and Myxobolus cerebralis (Höfer 1903) have marine and Western Europe origins, respectively (Table 1). I. hoferi was originally described from cultured brown trout Salmo trutta Linnaeus 1758 and brook trout Salvelinus fontinalis (Mitchill 1814). Most of its worldwide records are from the open sea, estuaries or diadromous fish, while numerous isolations from freshwater fish species have been associated with the marine environment, particularly in aquaculture where raw marine fish were frequently used as feed (McVicar, 2011). The emergence of myxozoan Myxobolus cerebralis (Höfer 1903) originates from late $19^{\text {th }}$ century Western Europe following the importation of naive nonnative rainbow trout Oncorhynchus mykiss (Walbaum 1792), from where the disease (Whirling disease) was translocated across the rest of the continent as well as spread to four others due to the increasing number of shipments of live and frozen rainbow trout (Hallett and Bartholomew, 2012). The origin of the caryophyllid cestode Atractolytocestus huronensis Anthony 1958 and monogean gill worm Dactylogyrus extensus Mueller and Van Cleave 1932 have been the subject of debate. These species were originally described from common carp Cyprinus carpio Linnaeus 1758 in the USA but were subsequently reported in Europe. The North American origin of the parasites is doubtful because common carp is not indigenous to this continent (Scholz et al., 2011), while the occurrence in Europe is puzzling because common carp is seldom imported from the USA to Europe, while shipments of Asian cyprinids, particularly koi carp, are a daily activity (Molnár et al., 2003). Gill worm D. extensus was discovered in the Amur River and described as $D$. solidus by Akhmerov in 1948, and it appears that the parasite was co-introduced during the planned shipments of Amur wild carp into Europe (Molnár, 2009). Most recent molecular data indicate higher genetic diversity and level of polymorphism in Chinese populations of $A$. huronensis compared to the populations from the USA and Europe, supporting the view of a far Eastern origin (Bazsalovicsová et al., 2018).

\section{Dates of first record, areas and pathways of introduction}

The lack of historical data restricts a reliable identification of co-introduction events, thus records are restricted to first observations, which in most cases occurred years if 
Table 1. Species, origin, areas and vectors of introduction, and current status of nonindigenous parasites introduced into fish farms and inland waters of Croatia

\begin{tabular}{lccccc}
\hline \hline Parasite & \multirow{2}{*}{ Origin $\begin{array}{c}\text { Date of } \\
\text { first record }\end{array}$} & $\begin{array}{c}\text { Pathways of Waterbody/ } \\
\text { introduction }\end{array}$ Area & $\begin{array}{c}\text { References } \\
\text { (for first record) }\end{array}$ \\
\hline
\end{tabular}

\section{Ciliophora}

Ichthyophthirius multifiliis Fouquet, 1876

AS

$$
?
$$

AS

T. hovorkai Achmerov, 1960

Myxobolus cerebralis (Höfer, 1903)

\section{Mesomycetozoea}

Ichthyophonus hoferi Plehn \& Mulsow (1911)

Dermocystidium koi Hoshina \& Sahara, 1950

\section{Platyhelminthes Monogenea}

Dactylogyrus vastator Nybelin, 1924

D. extensus Mueller \& Van Cleave, 1932

D. anchoratus Dujardin, 1845

Gyrodactylus elegans (Nordmann, 1832)

\section{Digenea}

Centrocestus formosanus (Nishigori, 1924)

\section{Cestoidea}

Khawia sinensis Hsu, 1935

Bothriocephalus acheilognathi (Yamaguti, 1934)

Atractolytocestus huronensis Anthony, 1958

\section{Arthropoda Copepoda}

Argulus japonicus Thiele, 1900

Lernaea cyprinacea Linnaeus, 1758

AS $\quad 2006$

$\begin{array}{ccccc}\text { MA } & \text { early 1970s } & \text { CC } & \text { TF } & \text { DI Fijan (1974) } \\ \text { AS } & 2005 & \text { CC } & \text { CF } & \text { COIT? Gjurčević et al (2008) }\end{array}$

$\begin{array}{lllll}\text { AS } & ? & \text { UK } & \text { CF } & \text { COIN Tomašec (1953) } \\ \text { AS } & ? & \text { UK } & \text { CF } & \text { COIT? Hacmanjek (2001) } \\ \text { AS } & ? & \text { UK } & \text { CF } & \text { COIN? Hacmanjek (2001) } \\ \text { AS } & ? & \text { UK } & \text { CF } & \text { COIN? Tomašec (1953) }\end{array}$

CC

$A Q$

UN Gjurčević et al (2007)

AS late 1970s NS CF COIN? Fijan (1982)

$\begin{array}{lllll}\text { AS } & 1972 & \text { CC } & \text { CF } & \text { COIN Kezić et al. (1975) } \\ \text { AS } & 2005 & \text { CC } & \text { CF } & \text { COIT } \begin{array}{l}\text { Gjurčević et al. } \\ (2009)\end{array}\end{array}$

Note: Origin (AS, Asia; WE, Western Europe; MA, Marine), Waterbody/Area of introduction (CF, Carp farms; TF, Trout farms; AQ, aquariums; OW, open water), suspected vectors of introduction (Hulme et al., 2008) (CC, contaminant of a imported commodity; NS, natural spread with host species; UK, unknown), and current status (Lymberdy et al., 2014); (COIT, co-introduced; COIN, Co-invasive; DI, disapeared; UN, unknown) 
not decades following the co-introduction. A little more than one-third of NIPs were recorded in the second part of the $20^{\text {th }}$ century, records of the first detection for more than one-third of NIPs are unknown, while the remaining records date after the 2000s. Carp farms were identified as locations of the first record in $75 \%$ (12) of the cases, whereas the remaining cases are recorded in trout farms (3) and aquariums (1). Suspected pathways of introduction are attributed to unintentional cointroduction as a contaminant of a commodity (infected fish), which accounts for over one third $(37.5 \%, 6)$ of NIPs, natural dispersal amounts to around one fourth (18.75\%, 3) of parasites, whereas the mode of transfer for nearly a half (43.75\%) of NIP species remains unknown (Table 1 ). The already mentioned ciliate I. multifiliis was unknown to cause epizootics in freshwater aquaculture up until the 1940s in the former Yugoslavia (Grujić, 1961). Initially, the disease was common in trout farms and aquariums, and to some extent in carp farms but rare in open waters (Tomašec, 1953a; Radojević and Tomašec, 1961). Similarly, the parasite was relatively unknown in Russia and Latvia before 1940, afterwards becoming a serious threat to carp culture (Dickerson, 2006; Kirjušina and Vismanis, 2007), while according to reports from England for the same period, the parasite did not exist there in the wild (Van Duijn, 1956 cited in Hoffman, 1967). Regular occurrences of the parasite in public and research aquariums of Western Europe intensified in the latter part of the $19^{\text {th }}$ century (Stiles, 1894), which could be associated with the establishment of commercial aquaculture production of exotic ornamental freshwater fish and the growth of the number of clubs and associations related to ornamental fishkeeping in Europe at that time (Novák et al., 2020). Aquaculture practices and techniques might have facilitated the transmission of the parasite between cold water and warm water aquaculture, for example, polyculture of trout and carp under certain conditions and stocking densities (Horvat, 1901). The parasite became widespread in salmonid hatcheries throughout Germany and the Netherlands from 1919 to 1928 (Buschkiel, 1937). The pathways and initial points of co-introduction into Croatian inland waters are unknown, but could possibly be associated with the intensification and expansion of aquaculture production, particularly of salmonids. For example, several new trout farms were constructed between 1918 and 1941, and most of these facilities produced juveniles for stocking open waters (Bojčić, 1982). Similarly, the first epizootics of the disease in Australian salmonid culture were associated with the co-introduction of the parasite on imported ornamental exotic fish species (i.e. goldfish and common carp) (Forwood et al., 2015). An alternative explanation might be found in historically numerous importations and translocations of common carp into Croatian aquaculture (Piria et al., 2016).

The first record and pathways of introduction are unknown for gill worms Dactylogyrus vastator Nybelin 1924, D. extensus, D. anchoratus Dujardin 1845, and Gyrodactylus elegans Nordmann 1832, which were either present by or appeared in the second half of the $20^{\text {th }}$ century on carp farms (Tomašec, 1953a; Fijan, 1974; Hacmanjek, 2001). These monogean parasites were co-introduced with goldfish and/or common carp from Asia to Europe as a result of international trade of ornamental fish (Hoffman, 1970; Hoffman and Schubert, 1984; Buchmann and Bresciani, 2006; Bauer and Hoffman, 1976; Bauer, 1991; Molnár, 2009; Trujillo-Gonzales et al., 2018).

Japanese fish louse Argulus japonicus Thiele, 1900 was first recorded in carp farms Poljana and Našice in 1953 (Stammer, 1959), while the date of the first record for anchor worm Lernaea cyprinacea Linnaeus 1758 remains elusive as the parasite had been rarely reported in warm water aquaculture up until the mid-1970s (Tomašec, 1953a; Fijan, 1974), but has subsequently been detected more frequently (Fijan, 1982). Similarly, in the rest of Europe, mass infections of common carp and other fish species with $L$. cyprinacea were not observed until the 1960s, but eventually became significantly prevalent in fish farms of Eastern Europe (Bauer, 1979). It is not known whether these parasites were co-introduced with imported carp or goldfish or had spread from other parts of Europe naturally with host fish species through watersheds. Namely, the former organism was first discovered in Spain in 1921, and subsequently in Germany, France, Italy, Poland, Czech Republic, Slovakia, Bosnia, Serbia, England and the Netherlands (Stammer, 1959; Holdich and Pöckl, 2007; Soes et al., 2010), whereas the latter was recorded in Italy, Poland, Hungary, Bulgaria, Latvia, Russia and other parts of Europe, presumably as a result of the international transport of aquarium, sport or food fishes (Lom and Hoffman, 1964; Hoffman, 1970; Bauer, 1979; Lester and Hayward, 2006; Kirjušina and Vismanis, 2007; Trujillo-Gonzales et al., 2018; Ahnelt et al., 2018). The parasites probably originated from historically numerous imports of goldfish, common carp and other exotic ornamental fish species from East Asia throughout Europe (Hoffman and Schubert, 1984; Novák et al., 2020) and/or by subsequent secondary co-introductions with imported Chinese major carps (Bauer, 1979).

Three species of Myxozoans parasites were reported in the aquaculture conditions of Croatia. Thelohanellus nikolskii Achmerov 1955, and T. hovorkai Achmerov 1960 were first recorded in carp farms in the early 1980s and 2015, respectively (Hacmanjek, 1985; Gjurčević et al., 2015), and are thought to likely be the result of natural dispersal thorough hydrological network of Eastern and Central Europe since the parasite's host species, Asian common carp Cyprinus carpio haematopterus Temminck \& Schlegel 1846, has not been introduced into Croatian aquaculture (Piria et al., 2016). Amur wild carp has not been intentionally introduced to geographic areas west of Ukraine, and possibly Romania, and according to Molnár (1982), the former parasite was first detected in 1979 in fish farms in East Hungary (bordering Romania), 
and by 1981 it was widespread in the country, including Transdanubian fish farms. The occurrence of the parasite was attributed to a natural spread with free-living common carp from adjacent watersheds through Ukraine and Romania, where Amur carp consignments were imported in 1955 and 1963, and early 1960s, respectively (Molnár, 1982; 1984a, b). Similarly, the parasite was noted for the first time in Vojvodina Province (Serbia) in 1980 (Ćirković, 1986 cited in Dyková and Lom, 1988). Dissemination of T. hovorkai Achmerov 1960 presumably occurred in a similar way and time in Hungary (Molnár and KovácsGayer, 1981), subsequently recorded in 1983 in Bulgaria and 1984 in Vojvodina (Dyková and Lom, 1988). In Croatia, besides the infection in domestic aquaculture stock, the parasite was also detected in two-year-old common carp imported from Slovenia (Gjurčević et al., 2015).

Whirling disease caused by $M$. cerebralis was first recorded in a trout farm in 1960, likely as a result of the importation of infected rainbow trout (Tomašec, 1960 cited in Bartholomew and Reno, 2002), however, details concerning the source from which the fish where imported are unknown. Up until the middle of the 1930s, the disease was known only in Germany, Denmark and Finland, however, unrestricted export of live rainbow trout following World War II facilitated the spread of the disease to most European countries by the early 1970s (Bartholomew and Reno, 2002).

The occurrence of Mesomycetozoeans I. hoferi and Dermocystidium koi Hoshina \& Sahara 1950, respectively, were first reported in the early 1970 s on a rainbow trout farm (Fijan, 1974) and carp farm in 2005 (Gjurčević et al., $2008 ; 2012$ ). The former parasite emerged as a result of the diet regime employed at the farm, which partly consisted of marine trash fish (Fijan and Maran, 1976), whereas the latter organism was probably co-introduced with common carp brood-stock imported from Hungary (Gjurčević et al., 2012). The first epizootics of $I$. hoferi were recorded in trout farms in Germany and France at the turn of the $20^{\text {th }}$ century and were associated with feeding practices of the time or contact with sympatric diadromous fish (McVicar, 2011). There is limited information concerning the history of the dissemination of $D$. koi throughout Europe (Dyková and Lom, 1992).

Besides the aforementioned Monogea (gill worms), Phylum Platyhelminthes (parasitic worms) is represented by species from Cestoda (tapeworms) and Trematoda (digenean flukes). The metacercariae of digenetic fluke Centrocestus formosanus (Nishigori 1924) were first recorded from a shipment of goldfish imported into a local pet shop from Singapore (Gjurčević et al., 2007). The parasite was detected in fourteen countries from North America, Europe, West Asia and Australia, following the importation of ornamental plants and fishes of Asian origin (Tolley-Jordan and Chadwick, 2012).

Three species of tapeworms have been recorded in Croatian aquaculture. Tapeworm Khawia sinensis Hsu 1935 was first recorded in carp farms in the mid-1970s
(Fijan, 1974; 1982) and has probably naturally dispersed with common carp. The species was co-introduced with Amur wild carp and first recorded in 1950 in the central part of the former USSR, in the mid-1950s in Byelorussia, Latvia and Lithuania, in western Ukraine in the early 1960s, and by 1974 it was reported in East Germany (Ivassik and Karpenko, 1967; Kulakovskaya and Ivasik, 1967; Hoffman, 1970; Bauer and Hoffman, 1976). The appearance in inland waters of Croatia most likely occurred via upstream dispersal through the Danube Basin (Molnár, 1984a; 2009). The Asian fish tapeworm Bothriocephalus acheilognathi Yamaguti 1934, first recorded in common carp fry and fingerlings on a carp farm in 1972, was probably unintentionally co-introduced with grass carp Ctenopharyngodon idella (Valenciennes 1844) broodfish imported from Hungary (Kezić et al., 1975). The first shipment of grass carps which arrived into Croatian aquaculture in 1966 underwent a strict prophylactic and quarantine regime, and no parasites were detected (Fijan, 1978). However, subsequent consignments of the species shipped to other fish farms throughout the country occurred regularly and had probably resulted in the co-introduction of the parasite (Fijan, 1982). In addition, the spread of the parasite between carp farms was also associated with translocations of stock as well as upstream and downstream dispersal from adjacent watersheds (Fijan, 1978). The caryophyllidean tapeworm $A$. huronensis was first recorded in common carp at two carp farms in 2005, and the most likely pathway of transfer was unintentional co-introduction with infected common carp imported from Hungary (Gjurčević et al., 2009). The first appearance of this parasite in Europe was in 1993 in Great Britain, and subsequently in Central Europe (Germany, Slovakia, Czech Republic) and Romania (Bazsalovicsová et al., 2011), including Hungary where it was first detected from common carp in 2001, presumably originating from the Czech Republic (Molnár et al., 2003). Molecular data of populations from North America and Europe indicated two mitochondrial cox1 haplotypes, one encompassing populations from continental Europe (Slovakia, Hungary, Croatia and Romania) and the second populations from the USA and UK, suggesting a possible two independent cases of introduction of the parasite to Europe (Bazsalovicsová et al., 2011; 2018).

\section{Status}

The distribution and prevalence of the protozoan $I$. multifiliis seem to have experienced dynamic changes in aquaculture conditions. From initial high prevalence in trout farms (as well as aquariums) (Tomašec, 1953a; 1967), the parasite became less frequent in cold water aquaculture, subsequently increasing in prevalence and intensity in carp farms, causing significant losses to fry culture of wels catfish Silurus glanis Linnaeus 1758, common carp as well as other species (Fijan, 1974). Presently, the parasite is frequently observed in aquaculture (both cold and warm water) and aquariums 
(Petrinec et al., 1999; Gjurčević et al., 2006; Dolšak, 2018; Oraić and Zrnčić, 2005; Oraić and Zrnčić, 2009). Likewise, the distribution in open waters seems to be increasing over time. The parasite was rare in open waters until the latter part of the $20^{\text {th }}$ century (Tomašec, 1967; Fijan, 1974) when it was noted that many fish species in open waters were carriers of the parasite (Fijan, 1982). At present, the parasite is regularly observed in native wild fish populations in open waters (Topić Popović et al., 2001; Zrnčić et al., 2009; Kurtović et al., 2009; Valić et al., 2015). Since the first record of T. nikolskii at several carp farms, it has been detected occasionally in warm water aquaculture establishments in other parts of the country with variable intensities, infecting common carp of all age groups (Hacmanjek, 1985). Currently, there is no available published data for the distribution, prevalence and intensities of infection in aquaculture and open waters. However, the parasite is reported frequently on some carp farms (Hacmanjek, 2001; Dolšak, 2018). The occurrence of $T$. hovorkai is difficult to resolve as the parasite was first recorded decades following cointroduction into the watersheds of neighbouring countries. The organism infects the connective tissues in the abdominal cavity and muscle of common carp, and infestations frequently go unnoticed by visual inspection (Molnár et al., 2019). Perhaps this is why the parasite was not recorded earlier as well as during monitoring surveys and border inspections of imported carp stocks in recent years. There have been no published reports of the parasite since the first detection in common carp yearlings and two-year-old fish (Gjurčević et al., 2015). M. cerebralis has been regularly occurring in trout farms in the years following co-introduction into Croatia, while there were no records of the disease in open waters and aquariums (Tomašec, 1967, Fijan, 1974). More recent monitoring data indicate that the disease is not present in aquaculture conditions (Oraić and Zrnčić, 2005; Oraić et al., 2011). The reason that the disease has not been emerging in the modern-day culture of rainbow trout is primarily due to switching production from earthen ponds to concrete raceways, thus eradicating the favourable environmental conditions for the definite host of the parasite (i.e. oligochaete worm Tubifex tubifex) (Fijan, 2006). Since the discovery of $I$. hoferi in a trout farm, the parasite has occurred in aquariums and other trout production facilities, however, there is no record of infections in wild or feral salmonid populations (Fijan, 1974; Fijan and Maran, 1976). Recent fish disease surveys substantiate that the disease is not present in aquaculture conditions (Oraić and Zrnčić, 2005; Oraić et al., 2011). Since the first detection of $D$. koi in carp farms (Gjurčević et al., 2008), there is no available published information on the distribution and prevalence of the parasite in aquaculture conditions and open waters of Croatia. However, it appears that the parasite occurs regularly in some carp ponds (Dolšak, 2018) and is considered a common parasite of common carp (Molnár et al., 2019). Gill worms $D$. vastator and $G$. elegans have been widely reported from warm water aquaculture, sometimes inflicting substantial losses in the production of common carp fry (Tomašec, 1967; Fijan, 1974; 1982), whereas limited published information is available concerning the distribution, prevalence of infection and host switching for $D$. extensus and $D$. anchoratus in aquaculture conditions (Hacmanjek, 2001), as well as for other exotic gill worms identified in this review. International records indicate that $D$. vastator was reported from silver carp Hypophthalmichthys molitrix (Valenciennes 1844), grass carp, as well as in species belonging to the Esocidae and Cobitidae (15 species), whereas infections with $D$. anchoratus were found in hosts from the Esociae, Gasterosteidae, Perciade and Salmonidae (20 species) (Trujillo-Gonzales et al., 2018) G. elegans was reported in indigenous fish species which are phylogenetically closely related to their invasive host species, however, knowledge on their capacity to host switch in non-indigenous environments is limited (Trujillo-Gonzales et al., 2018). Dactylogyrus and Gyrodactylus species are regularly detected in shipments of ornamental fish for the aquarium trade (Gjurčević et al., 2006), in carp farms (Tomec et al., 1995; Petrinec et al., 1999; Oraić and Zrnčić, 2009; Dolšak, 2018), trout farms (Oraić and Zrnčić, 2005, Oraić et al., 2011) and in open waters (Valić et al., 2015), however, they are rarely determined at species level. The digenetic trematode $C$. formosanus has been detected in one consignment of goldfish, and at present the establishment of the parasite in Croatia is unlikely, as it requires the invasive mollusc host, Melanoides tuberculata, to complete its life cycle (Tolley-Jordan and Chadwick, 2012). However, the snail was reported in some European Member States such as France, Germany, Austria, Italy and Poland, but was mostly associated with thermally polluted waters systems (Maciaszek et al., 2019). Although the snail has been introduced to nearly all continents and has successfully invaded many countries in temperate regions, the populations do not establish in water temperatures less than $18^{\circ} \mathrm{C}$ and are mostly found in warm water springs or artificially heated ponds (Tolley-Jordan and Chadwick, 2012). Tapeworms $K$. sinensis and S. acheilognathi are frequently reported from farmed common carp in Croatia (Petrinec et al., 1999; Fijan, 1974; 2006; Hacmanjek, 2001; Gjurčević et al., 2009; Gjurčević, et al., 2012; Dolšak, 2018). There is no published record of $K$. sinensis infections in other warm water species, however, international records indicate that infections occur also in grass carp and black carp Mylopharyngodon piceus (Richardson 1846) (Oros et al., 2009). Recently, the parasite was detected in wild common carp (Valić et al., 2015), suggesting that self-sustaining populations are established in open waters. Infections with $B$. acheilognathi have been reported in grass carp, common carp and other fish species such as silver carp, bighead carp Hypophthalmichthys nobilis (Richardson 1845), tench Tinca tinca (Linnaeus 1758), goldfish and wels catfish 
(Fijan, 1974, 2006). The parasite was recorded in 312 freshwater fish species, the most frequent records being from common carp and grass carp, followed by silver carp and Mosquitofish Gambusia affinis (Baird \& Girard 1853) (Kuchta et al., 2018). Earlier records from Eastern Europe indicate that the parasite is, in addition to aquaculture, also distributed in open waters (Kirjušina and Vismanis, 2007), however, there is little available data of infections from wild populations (Fijan, 2006). Caryophyllidean tapeworm $A$. huronensis is widespread in fish farms across the country (Gjurčević et al., 2012; Dolšak, 2018). There is limited available information on infections of wild fish populations in inland waters of Croatia, however, in 2014 the parasite was detected in wild common carp from the Kupa River Basin (Sava River Catchment) (Valić et al., 2015). In addition, the parasite was recently detected in wild freshwater bream Abramis brama (Linnaeus 1758) and roach Rutilus rutilus (Linnaeus 1758), although these are considered accidental occurrences (Oros et al., 2009). Branchiurid crustacean $A$. japonicus has not been reported since the first detection in carp farms in Central and Eastern Croatia and no other record of its presence in aquaculture and open waters exists. However, unidentified Argulus species occur in some carp farms (Tomec et al., 1995; Dolšak, 2018). The cyclopoid copepod anchor worm L. cyprinacea has probably invaded much of the inland waters of the continental part of Croatia. Recent surveys indicated Lernaea spp. as the most common ecto-parasite in warm water aquaculture (Oraić and Zrnčić, 2005; Dolšak, 2018) and is even reported from large wild fish from open waters (Fijan, 2006), although there is no information concerning species involved in host switching. International records indicated infections in more than 60 fish species, some of which are of particular interest for warm water aquaculture (Lester and Hayward, 2006; Trujillo-Gonzales et al., 2018).

\section{DISCUSSION}

The findings of this review demonstrate that fish stockings related to aquaculture presented a significant pathway of parasite co-introduction into Croatian inland waters. Accordingly, carp and trout farms were identified as initial points of entry for the majority of NIPs. The trend of first records has been progressively increasing in numbers following intensification and diversification of aquaculture activities in the second part of the $20^{\text {th }}$ century (Bojčić, 1982), and are particularly associated with the introductions of Chinese major carps as well as unrestricted importation and translocation of other species of high commercial or recreational interest (e.g. rainbow trout, common carp). Indeed, the incidences of the most important aquatic animal disease epidemics have been associated with the development and intensification of aquaculture production, specifically with the introduction of alien species (Oidtmann et al., 2011). There is no sufficient evidence in the published records that would indicate conclusively the precise status of particular parasites, however, it is clear that at least some of the identified alien parasite species have become co-introduced and co-invasive at local carp farms. However, nationwide veterinary surveys are needed to determine the overall parasitic fauna composition in both warm water and cold water freshwater aquaculture, as well as their distribution and prevalence of infections, and the ability to switch between hosts. The importance of certain non-native parasites has seen a decreasing trend in Europe. For example, the veterinary significance of $K$. sinensis to aquaculture production has reduced in the last decades, presumably due to a more recent co-introduction of $A$. huronensis (Oros et al., 2009; Scholz et al., 2011). It would be interesting to determine the prevalence of both parasites in Croatian aquaculture as well as their interactions and impact on common carp culture. The disappearance of some parasites from aquaculture conditions can be attributed to the technological upgrades of culture systems and husbandry methods, and the rise in health and sanitary standards of production. However, such measures in some cases are insufficient. For example, although formulated feeds almost completely replaced feeding with raw marine fish, infections with I. hoferi are still reported regularly in cultured salmonids (McVicar, 2011) and ornamental fish species (Zadeh et al., 2014). Yet in some cases, technological upgrades contributed to parasite eradication. Since its initial discovery by Stammer (1959), A. japonicus is not reported in warm water aquaculture in Croatia, probably due to changes and upgrades of the heavily manured, clay soiled fish ponds, as this parasite favours higher $\mathrm{pH}$ value of alkaline water. Application of insecticides can also be the reason for rare reports of this parasite in some countries since 1980 (Paperna, 1991). Improved husbandry practices and management, as well as developed guidelines and protocols for eradication of certain diseases from salmonid aquaculture, have been extremely efficient in Europe, therefore, for example, M. cerebralis (i.e. Whirling disease) was removed from the OIE list of diseases in 1993 (Bartholomew and Reno, 2002). Besides having an adverse effect on cultured species, NIPs may have a severe economic impact on the profitability of aquaculture establishments. Shinn et al. (2015b) estimated that parasites amount to the annual loss of $5.8-16.5 \%$ of the value of the aquaculture (both freshwater and marine) production sector in the United Kingdom. Unfortunately, there has been no extensive and detailed research on the economic impact of parasite infections in warm or cold water aquaculture in Croatia. Fijan (1982) estimated that, in the period of 10 years from their co-introduction in the 1970s, tapeworms B. acheilognathi and K. sinensis caused significant economic losses (mortalities, treatments) to warm water aquaculture of S. R. Croatia, which amounted to around $\$ 2$ million. Calculating precise figures for the effect of disease on aquaculture production is difficult due to the interaction of several predisposing and contributing 
factors, which impact the production cycle, such as production scale, available resources, husbandry practices, timely and correct determination of the parasite at farm level, poor record-keeping, poor environmental quality and other factors that may cause stress, hence the economic impact of parasitic disease is only possible through estimation (Shinn et al., 2015b). Although estimating the economic impact of each individual case of parasite infection is complicated, a rough estimate of losses in the hatchery and grow-out production of $20 \%$ and $1 \%$ to $10 \%$, respectively, were proposed (Shinn et al., 2015a). In some countries, the economic loss in warm water aquaculture due to disease reaches $10-20 \%$, in some cases even higher, and even though major causes of epizootics are viral and bacterial diseases, it was suggested that $1 / 4$ of the total losses were attributed to parasite infections (Bauer, 1979). Therefore, future efforts in research and monitoring programs need to be directed toward the determination of the native and non-native parasite ratios and prevalence in species of high commercial value in warm water and cold water aquaculture (e.g. common carp, rainbow trout). Also, a model of estimating and predicting the impact of parasite infections on production costs, which could be used in strategic planning of sanitary and prophylactic measures and actions, should be developed and applied. These studies would require cooperation between the scientific and governmental institutions, and the production sector. The aim would consist of gathering data on disease risk and history through annually consecutive reporting, including information and samples on parasite infection prevalence and mortality, diagnostic results, information on stock introduction and translocation, implemented chemotherapeutants, fallowing periods and stocking biomass (Sim-Smith and Diggles, 2019). These data, in addition to production records (e.g. feed conversion ratio, growth rates), might potentially serve to develop a model that would be used to roughly estimate direct and indirect losses in the production cycle. However, often the lack of support by the industry and unwillingness to participate might hinder conducting research activities and surveillance programs (Sim-Smith and Diggles, 2019). Parasite fauna of native and non-native fish species has not been studied thoroughly in wild populations, and a small number of published records and data are available on the distribution and prevalence of NIPs in inland waters of the continental part of Croatia, as well as in the lotic and lentic water bodies of the coastal areas belonging to the Adriatic Sea Basin (Mladineo et al., 2009; Topić Popović et al., 2001; Valić et al., 2005; Zrnčić et al., 2009; Kurtović et al., 2009; Vardić Smrzlić et al., 2013; Valić et al., 2015). The fish fauna of the hydrological system of the Adriatic Sea Basin is rich in endemic fish species and, as part of eight biogeographical regions of the Balkan peninsula, forms a European hot-spot of biodiversity, especially in cyprinid species (Oikonomou et al., 2014). Inland waters of the Adriatic Basin within the Croatian territory are inhabited by 38 endemic fish species, significantly contributing to the overall European fish biodiversity (Ćaleta et al., 2015). Considering that extensive historical and contemporary introductions and/ or translocations of non-native and native fish species in water catchments of the Adriatic Sea Basin resulted in the transfer of 20 native and 13 non-native fish species (Pofuk et al., 2017), it is highly probable that other non-native parasite species were co-translocated during decades of transfers and stockings. Indeed, tapeworms (cestodes) and thorny-headed worms (acanthocephalans), found in fish native to the Danube River Basin (Babić, 1935), have been recorded in the Cetina River on the non-native brown trout (Mladineo et al., 2009), while in the Krka River, unidentified parasites of the same groups were detected in non-native brown and rainbow trout (Valić et al., 2005). In addition, gill worms from Dactylogyrus and Gyrodactylus sp., as well as fish louse Argulus sp., were recorded from non-native and endemic fish species from the Krka River (Valić et al., 2005). The endemic acanthocephalan parasite Dentitruncus trutae Šinžar 1955 (synonym Pseudorhadinorhynchus salmothymi Rukavina \& Goric in Cankovic, Delic, Kiškarolj \& Rukavina, 1968) has been reported in non-native brown trout in the Krka River (Topić Popović et al., 1999). However, little information is available on co-translocated parasites that can host switch to endemic fish species or of the potential spill-back events from non-native to endemic fish species. Nonindigenous fish species may harbour endemic parasites, acquiring between 1 and 15 endemic parasites (mean \pm $\mathrm{SE}: 4.9 \pm 0.7$ ), main taxonomic groups being nematodes, trematodes or acanthocephalans, indicating that parasites with complex life cycles are as likely to be included in spillback events as species with direct life cycles (e.g. monogeneans, copepods) (Poulin et al., 2011). Most recently, gill worm $D$. vastator has been recorded on endemic species Dalmatian barbelgudgeon Aulopyge huegelii Heckel 1843 and Italian barbell Barbus plebejus Bonaparte 1839 from the Cetina and Krka river systems, respectively (Benovics et al., 2020). In addition, $L$. cyprinacea was documented recently for the first time in gobionellid species endemic to the Adriatic Basin, namely in Adriatic dwarf goby Knipowitschia panizzae (Verga 1841) and Canestrini's goby Pomatoschistus canestrinii (Ninni 1883), and although these species are not optimal hosts, they may potentially harbour and transmit the parasite to other native species (Ahnelt et al., 2018).

Ciliate I. multifiliis may be considered co-invasive in the majority of inland waters as observations of infestation from wild fish populations are frequently reported (Topić Popović et al., 2001; Valić et al., 2005; Zrnčić et al., 2009; Kurtović et al., 2009; Valić et al., 2015). Unfortunately, records of other non-indigenous parasites in wild fish populations are non-existent or limited in taxonomic determination and there is no research conducted on the potential impact of non-native fish parasites on native fish fauna as well as on community structure and 
species interactions. However, determination of the potential impact of NIPs on aquatic biodiversity requires surveillance of fish populations over long time intervals and several water catchments for comparison, thus having high economic costs (Gozlan et al., 2006). It is established that some of the NIPs identified in this review have been implicated to spread naturally throughout cross-continental waterways and basins, and several species have become co-invasive in their novel areas of distribution, in some cases decimating naïve populations of native fish species (Paperna, 1991; Scholz, 1999; Matthews, 2005; Lester and Hayward, 2006; Holdich and Pöckl, 2007; McVicar, 2011; Hallett and Bartholomew, 2012; Tolley-Jordan and Chadwick, 2012; Faruk, 2018; Kuchta et al., 2018; Trujillo-Gonzales et al., 2018; Molnár et al., 2019). This impact might be amplified in areas of high endemism as ecosystems with high biodiversity could act as a source pool for novel pathogens (Keesing et al., 2010). They can trigger the emergence of infectious diseases, which may constitute a considerable risk to biodiversity by means of biomass loss and extinction of host species, in particular because of lack of shared evolutionary history between NIP and naïve host species or ecosystem (Britton et al., 2011). In turn, loss of biodiversity may lead to increased parasite transmission, for example, if the predation and competition on reservoir hosts are reduced, therefore increasing their density, or by shifts in species richness (Kessing et al., 2010). In addition, repeated or secondary introductions of host species may help facilitate the introduction, establishment and spread of their associated parasite fauna as the imported host populations experience demographic expansion (Torchin and Mitchell, 2004). However, the long-term impact of NIP invasion is hard to predict due to causality of several factors. These include parasite life strategy, the levels of virulence, pathogenicity and specificity, the presence of natural enemies, and the evolutionary responses of hosts and parasites, thus no empirical studies exist that explain the structural impact of NIPs on food webs and networks (Médoc et al., 2017). Hence, there is a need to research activities into the potential presence and impact of NIPs on native wild fish populations and aquatic ecosystems, particularly endemic and endangered species (Mrakovčić et al., 2006; Ćaleta et al., 2015), which may, in addition to already high demographic pressure by decades of stocking and restocking with non-native fish species (Pofuk et al., 2017), be seriously threatened by emerging infectious diseases (e.g. Sphaerothecum destruens) (Gozlan et al., 2005; Sana et al., 2017; Spikmans et al., 2020). However, epizootics in wild fish populations due to the introduction of an NIP largely go unnoticed and the potential negative impact that drives long-term gradual declines is hard to quantify (Gozlan et al., 2006). One possible way of tackling such issues in settings with low resources is that scientific institutions establish cooperation and awareness raising events with sport fishermen, including training programs for record-keeping of biological data, visual inspection and identification. These, in conjunction with monitoring data, could be used to indicate population declines in the field, and be the base for appropriate conservation programs and actions.

The establishment of an NIP in aquaculture conditions may eventually lead to contact with sympatric wild populations of fish, which might become permanent reservoirs of infections, eradication programs generally being ineffective once the parasite is established (Oidtmann et al., 2011). However, the establishment of a parasite is seldom detected (Torchin and Mitchell, 2004) and the effects may develop and manifest over long periods, complicating the identification of the initial source of infection (Whittington and Chong, 2007). Disease surveillance programs are advantageous for the early and rapid detection and/or prevention of parasite spread. Therefore, timely and regular surveillance programs could significantly contribute to the security of stocks in aquaculture production and wild, native populations from epizootics, safeguard of trade, border biosecurity and disease detection, prevention and spread, as well as to economic benefits (Sim-Smith and Diggles, 2019). Although some invasive invertebrate host species, which may harbour ichthyozoonotic parasites (e.g. Centrocestus formosanus), have not yet been detected in continental waters of Croatia, climate change predictions may drive geographic range expansion of invasive parasite fauna and associating emerging diseases (Daszak et al., 2000). Indeed, climate warming may increase pathogen development and survival as well as disease transmission and host susceptibility (Harvell et al., 2002). In addition, few localities with available environmental conditions (i.e. warmer temperatures) exist in inland waters of Croatia, such as discharge canals from heating plants (Landeka et al., 2015), or warm water from thermal springs. The record of non-native parasites laid out in this review is not exhaustive and may not necessarily represent the actual number of species, as it primarily reflects the general research effort which was directed significantly more toward microparasitic diseases of international importance. Hence, the record may be considered as a preliminary checklist. Nearly one hundred NIP species were introduced into European water systems (Blanc, 2001), some of which, mostly of Asian origin, may present a potential health risk to cultured and wild fish populations (Musselius, 1969; Hoffman, 1970; Bauer, 1991; Molnár, 1984a, 2009). Hence, thorough and regular monitoring programs are needed to identify potential novel NIPs in aquaculture conditions, their prevalence and economic impact on production. Further, surveillance programs with mandatory reporting of notifiable disease and elevated mortality in all stages of production (e.g. hatchery, grow-out), regular testing and inspection prior to importation and translocation of stock are a prerequisite for disease detection and prevention, establishing freedom from disease status, extension of knowledge and capabilities as well as advanced reputation (Sim- 
Smith and Diggles, 2019). In addition, an opportunity exists for a multidisciplinary approach to cooperation between management, conservationists, biologists, fishery experts, veterinarians, sport and artisanal fishermen and other interested stakeholders to jointly conduct research and surveillance programs on wild fish populations, particularly endemic and endangered fish species of the Adriatic Sea Basin. The possibility of the establishment of some extremely pathogenic parasites (e.g. Asian tapeworm) in native freshwater ecosystems raises concerns of the potential negative impact on naïve native fish species and community structure, and therefore to overall biodiversity. Future efforts should be directed toward prevention of further NIP co-introduction by stricter regulating imports of exotic aquatic species as well as stocks of species of high commercial value (e.g. common carp), more frequent inspections, registration of translocations of aquaculture stock within the country and between establishments and ponds, tighter and more regular monitoring and surveillance programs, as well as educational and information programs for the fish health services, aquaculture industry, ornamental trade, sport and artisanal fishermen and the general public with the aim of raising awareness of the potentially negative impact of NIP co-introduction to aquaculture sustainability and native biodiversity.

\section{ACKNOWLEDGEMENTS}

The author is grateful to associate professor Emil Gjurčević, PhD (Faculty of Veterinary Medicine, Zagreb) for granting access to relevant literature and for constructive comments on the manuscript. In addition, comments by Dražen Oraić, PhD (Croatian Veterinary Institute) on the manuscript are also acknowledged. Helpful suggestions from anonymous reviewers are also greatly appreciated.

\section{ALOHTONE VRSTE PARAZITA SLATKOVODNIH RIBA U KOPNENIM VODAMA REPUBLIKE HR- VATSKE}

\section{SAŽETAK}

Alohtona fauna parazita slatkovodnih vrsta riba nije detaljno istražena u Republici Hrvatskoj unatoč dugoj povijesti unosa i prijenosa stranih vrsta riba u kopnene vode. Negativne posljedice za proizvodnju u akvakulturi i divlje vrste riba često su povezivane s unosom alohtonih vrsta parazita. Stoga ovaj članak nastoji izložiti povijesni pregled lokacija, vremenskih perioda i načina unosa alohtonih vrsta parazita riba u kopnene vode $\mathrm{i}$ time sastaviti listu vrsta. Ukupno, 16 alohtonih vrsta parazita zabilježeni su u kopnenim vodama Republike Hrvatske, a ribnjačarstva i ribogojilišta su utvrđena kao početne točke njihovog unosa. Međutim, postoji malo objavljenih podataka o ukupnoj prevalenciji infekcija, kao i ekonomskom utjecaju na akvakulturnu proizvodnju. Osim toga, ograničene informacije su dostupne o prisutnosti i potencijalnom ekološkom utjecaju egzotičnih parazita na autohtone vrste, posebno na endemsku ihtiofaunu u područjima visoke biološke raznolikosti, poput vodenih tijela Jadranskog slijeva. Stoga, postoji žurna i nužna potreba za multidisciplinarni pristup u suradnji između različitih dionika, uključujući državne institucije i znanstvene institucije u biološkoj, poljoprivrednoj i u veterinarskoj disciplini te sektora proizvodnje, s ciljem opsežnih istraživanja kako bi se utvrdio potencijalni utjecaj na proizvodnju akvakulture te autohtone populacije riba visoke konzervacijske vrijednosti.

Ključne riječi: egzotični, patogen, introdukcije, slatkovodne ribe

\section{REFERENCES}

Ahnelt, H., Konecny, R., Gabriel, A., Bauer, A., Pompei, L., Lorenzoni, M., Sattmann, H. (2018): First report of the parasitic copepod Lernaea cyprinacea (Copepoda: Lernaeidae) on gobioid fishes (Teleostei: Gobonellidae) in southern Europe. Knowledge \& Management of Aquatic Ecosystems, 419, 34, 1-6.

Alderman, D. J. (1996): Geographical spread of bacterial and fungal diseases of crustaceans. Revue Scientifique et Technique-Office International des Epizooties, 15, 2, 603-632.

Altizer, S., Bartel, R., Han, B. A. (2011): Animal migration and infectious disease risk. Science, 331, 6015, 296-302.

Babić, I. (1935): On the findings of endoparasitic worms in freshwater fish. Veterinarski arhiv, 5, 356-367. (in Croatian with German abstract)

Balon, E. K. (2004): About the oldest domesticates among fishes. Journal of fish Biology, 65, 1, 1-27.

Bartholomew, J. L., Reno, P. W. (2002): The history and dissemination of whirling disease. In: Bartholomew, JL, Wilson, C, editors, Whirling Disease: Reviews and Current Topics, American fisheries society symposium 29; 2001 February, Salt Lake City, Utah, USA, American Fisheries Society, p. 1-22.

Bauer O. N. (1979): Parasitic infections of cultured fishes. Parazitologiya, 13, 4, 377-385. (in Russian with English abstract)

Bauer, O. N. (1991): Spread of parasites and diseases of aquatic organisms by acclimatization: a short review. Journal of Fish Biology, 39, 5, 679-686.

Bauer, O. N., Hoffman, G. L. (1976): Helminth range extension by translocation of fish. pp. 163-172. In: Page, L. A. (ed), Wildlife diseases. Springer, Boston, MA, USA. 686pp.

Bazsalovicsová, E., Králová-Hromadová, I., Štefka, J., Scholz, T., Hanzelová, V., Vávrová, S., Szemes, T., Kirk, R. (2011): Population study of Atractolytocestus huronensis (Cestoda: Caryophyllidea), an invasive parasite of common carp introduced to Europe: mitochondrial cox1 haplotypes and intragenomic ribosomal ITS2 variants. Parasitology research, 109, 1, 125-131.

Bazsalovicsová, E., Králová-Hromadová, I., Xi, B. W., Štefka, J. (2018): Tour around the globe: the case of invasive tapeworm Atractolytocestus huronensis (Cestoda: Caryophyllidea), a 
parasite of common carp. Parasitology international, 67, 4, 366-374.

Benovics, M., Desdevises, Y., Šanda, R., Vukić, J., Šimková, A. (2020): Cophylogenetic relationships between Dactylogyrus (Monogenea) ectoparasites and endemic cyprinoids of the north-eastern European peri-Mediterranean region. Journal of Zoological Systematics and Evolutionary Research. 58, 1, 1-21.

Blanc, G. (2001): Introduction of pathogens in European aquatic ecosystems: attempt of evaluation and realities. Pp 37-56. In Uriarte, A. and Basurco, B. (eds), Environmental impact assessment of Mediterranean aquaculture farms. Proceedings of the Seminar of the CIHEAM Network on Technology of Aquaculture in the Mediterranean (TECAM), CIHEAM, Zaragoza, Spain. 213pp.

Bojčić, C. (1982): Centennial development of fish culture on the grounds of Yugoslavia. Ribarstvo Jugolavije, 37, 4-5-6, 76-82. (in Croatian with English abstract)

Boonthai, T., Herbst, S. J., Whelan, G. E., Van Deuren, M. G., Loch, T. P., Faisal, M. (2017): The Asian fish tapeworm Schyzocotyle acheilognathi is widespread in baitfish retail stores in Michigan, USA. Parasites \& vectors, 10, 1, 1-10.

Britton, J. R. (2013): Introduced parasites in food webs: new species, shifting structures? Trends in ecology \& evolution, 28, 2, 93-99.

Britton, J. R., Pegg, J., Williams, C. F. (2011): Pathological and ecological host consequences of infection by an introduced fish parasite. PLoS One, 6, 10, 1-8.

Buchmann, K., Bresciani, J. (2006): Monogenea (Phylum Platyhelminthes). pp 297-345. In Woo, P. T. K. (ed), Fish diseases and disorders. Vol. 1: Protozoan and Metazoan Infections, $2^{\text {nd }}$ Edition. CAB International. 791pp.

Buschkiel, A. L. (1937): Neue Beiträge Zur Kenntnis Des Ichthyophthirius Multifiliis Fouquet. Archives Néerlandaises de Zoologie, 2, 1, 178-224.

Cardinale, B. J., Emmett Duffy, J., Gonzales, A., Hopper, D. U., Perrings, C., Venail, P., Narwani, A., Mace, G. M., Tilman, D., Wardle, D. A., Kinzig, A. P., Daily, G. C., Loreau, M., Grace, J. B., Larigauderie, A., Srivastava, D. S., Naeem, S. (2012): Biodiversity loss and its impact on humanity. Nature, 486, 59-67.

Ćaleta, M., Buj, I., Mrakovčić, M., Mustafić, P., Zanella, D., Marčić, Z., Duplić, A., Mihinjač, T., Katavić, I. (2015): Croatian Endemic Fish. Croatian Environment Agency, 116pp

Ćaleta, M., Marčić, Z., Buj, I., Zanella, D., Mustafić, P., Duplić, A., Horvatić, S. (2019): A Review of Extant Croatian Freshwater Fish and Lampreys: Annotated list and distribution. Croatian Journal of Fisheries, 77, 3, 137-234.

Dashu, N., Lien-Siang, L. (1960): Studies on the morphology and life cycle of Ichthyophthirius multifiliis and its control, with a description of a new species. Acta Hydrobiologica Sinica, 2, 197-235. (in Chinese with English abstract)

Daszak, P., Cunningham, A. A., Hyatt, A. D. (2000): Emerging infectious diseases of wildlife - threats to biodiversity and human health. Science, 287, 5452, 443-449.

Dickerson, H. W. (2006): Ichthyophthirius multifiliis and Cryptocaryon irritans (Phylum Ciliophora). pp. 116-154. In Woo, P. T. K. (ed.), Fish diseases and disorders. Vol. 1: Protozoan and Metazoan Infections, $2^{\text {nd }}$ Edition. $C A B$ International. 791pp.

Dolšak, I. (2018): Health status of common carp (i.e. carp fry, one-year old and two-year old carp) on fish farm Poljana. University of Zagreb: Faculty of Veterinary Medicine.
Department for Biology and Pathology of Fish and Bees. 33 p. (in Croatian with English abstract)

Dunn, A. M. (2009): Parasites and biological invasions. Advances in parasitology, 68, 161-184.

Dyková, I., Lom, J. (1988): Review of pathogenic myxosporeans in intensive culture of carp (Cyprinus carpio) in Europe. Folia Parasitologica, 35, 4, 289-307.

Dyková, I., Lom, J. (1992): New evidence of fungal nature od Dermocystidium koi Hoshina and Sahara, 1950. Journal of Applied Ichthyology, 8, 1-4, 180-185.

Faruk, A. R. (2018): Fish parasite: infectious diseases associated with fish parasite. pp. 154-176. In Bari, L., Yamazaki, K. (eds) Seafood Safety and Quality. $1^{\text {st }}$ Edition. Boca Raton. CRC Press. 332pp.

Fijan, N. (1971): Measures for disease control on fish farms. Ribarstvo Jugoslavije, 26, 2, 29-31. (in Croatian)

Fijan, N. (1974): Diseases of fish and crustaceans. Sveučilište u Zagrebu, Veterinarski fakultet. Sveučilišna naklada Liber, Zagreb. 105pp. (in Croatian)

Fijan, N. (1978): The most important diseases of herbivorous fishes. Ribarstvo Jugoslavije, 33, 4, 96-101. (in Croatian)

Fijan, N. (1982): Diseases and enemies of fishes. pp. 439-513. In: Habeković, D., Bojčić, C. (eds), Slatkovodno ribarstvo. Jugoslavenska medicinska naklada. Poslovna zajednica slatkovodnog ribarstva Jugoslavije, Ribozajednica Zagreb. 605pp. (in Croatian)

Fijan, N. (2006): Protection of fishes health. Poljoprivredni fakultet u Osijeku. 392pp. (in Croatian)

Fijan, N., Maran, B. (1976): A case of Ichthyosporidiosis in rainbow trout. Veterinarski arhiv. 46, 3-4, 65-67. (in Croatian with English abstract)

Forwood, J. M., Harris, J. O., Landos, M., Deveney, M. R. (2015): Life cycle and settlement of an Australian isolate of Ichthyophthirius multifiliis Fouquet, 1876 from rainbow trout. Folia parasitologica, 62, 1, 13-13.

Froese R. Pauly D. (eds) (2020): FishBase (version Feb 2018). In: Species 2000 \& ITIS Catalogue of Life, 2020-06-04 Beta (Roskov Y.; Ower G.; Orrell T.; Nicolson D.; Bailly N.; Kirk P.M.; Bourgoin T.; DeWalt R.E.; Decock W.; Nieukerken E. van; Penev L.; eds.). Digital resource at www.catalogueoflife.org/ col. Species 2000: Naturalis, Leiden, the Netherlands. ISSN 2405-8858.

Galli, P., Strona, G., Benzoni, F., Crosa, G., Stefani, F. (2007): Monogenoids from freshwater fish in Italy, with comments on alien species. Comparative Parasitology, 74, 2, 264-272.

Gjurčević, E., Petrinec, Z., Matašin, Ž., Kozarić, Z. (2006): Parasites infections of goldfish (Carrassius auratus L.). Ribarstvo, 64, 1, 19-26. (in Croatian with English abstract)

Gjurčević, E., Petrinec, Z., Kozarić, Z., Kužir, S., Kantura, V. G., Vučemilo, M., Džaja, P. (2007): Metacercariae of Centrocestus formosanus in goldfish (Carassius auratus L.) imported into Croatia. Helminthologia, 44, 4, 214-216.

Gjurcević, E., Bambir, S., Kozarić, Z., Kužir, S., Gavrilović, A., Pašalić, I. (2008): Dermocystidium infection in common carp broodstock (Cyprinus carpio L.) from Croatia. Bull. Eur. Assoc. Fish Pathol., 28, 6, 222-229.

Gjurčević, E., Bambir, S., Beck, A. (2009): Atractolytocestus huronensis Anthony, 1958 from farmed common carp in Croatia. In: $14^{\text {th }}$ EAFP International Conference "Diseases of Fish and Shellfish": 2009 September 14-19, Prague, p. 235235

Gjurčević, E., Beck, A., Drašner, K., Stanin, D., Kužir, S. (2012): Pathogenicity of Atractolytocestus huronensis (Cestoda) 
for cultured common carp (Cyprinus carpio L.). Veterinarski arhiv, 82, 3, 273-282. (in English with Croatian abstract)

Gjurčević, E., Vlahek, I., Drašner, K., Matanović, K., Kužir, S. (2015): Thelohanellus hovorkai (Myxosporea) in farmed common carp (Cyprinus carpio carpio): two cases from Croatia. In: Proceedings of the $6^{\text {th }}$ International Scientific Meeting Days of veterinary medicine; 2015, Pendovski Lazo - Skopje: STV Prizma, p. 66-66

Gozlan, R. E., St-Hilaire, S., Feist, S. W., Martin, P., Kent, M. L. (2005): Disease threat to European fish. Nature, 435, 7045, 1046-1046.

Gozlan, R. E., Peeler, E. J., Longshaw, M., St-Hilaire, S., Feist, S. W. (2006): Effect of microbial pathogens on the diversity of aquatic populations, notably in Europe. Microbes and Infection, 8, 5, 1358-1364.

Grujić, M. (1961): Ichthyofthiriasis and it's control in fishponds. Ribarstvo Jugoslavije, 16, 5, 125-136. (in Croatian)

Hacmanjek, M. (1985): Telohanelosis - a more and more frequent disease on Yugoslav fish farms. Ribarstvo Jugoslavije, 40, 4-56, 94-96. (in Croatian with English abstract)

Hacmanjek, M. (2001): Occurrence and importance of fish parasites on the fish farms Narta and Lipovljani. Sveučilište $u$ Zagrebu, Veterinarski fakultet. Disertacija. 167p.

Hallett, S. L., Bartholomew, J. L. (2012): Myxobolus cerebralis and Ceratomyxa shasta. pp. 131-162. In Woo, P. T. K., Buchmann, K. (eds), Fish parasites, Pathobiology and Protection. CAB International. 383pp.

Harvell, C. D., Mitchell, C. E., Ward, J. R., Altizer, S., Dobson, A. P., Ostfeld, R. S., Samuel, M. D. (2002): Climate warming and disease risks for terrestrial and marine biota. Science, 296, 5576, 2158-2162.

Hedrick, R. P. (1996): Movements of pathogens with the international trade of live fish: problems and solutions. Revue scientifique et technique-Office international des épizooties, 15, 2, 523-528.

Hoffman, G. L. (1967): Parasites of North American Freshwater Fishes. Berkeley, University of California Press. London, Cambridge University Press. 486pp.

Hoffman, G. L. (1970): Intercontinental and transcontinental dissemination and transfaunation of fish parasites with emphasis on whirling disease (Myxosoma cerebralis). pp. 6981. In Snieszko, S. F. (ed), A symposium on diseases of fishes and shellfishes. Special Publication No. 5. American Fisheries Society Washington, D.C. 526pp.

Hoffman, G. L. (1999): Parasites of North American Freshwater Fishes. Second Edition. Comstock Publishing Associates, Cornell University Press. Ithaca and London. 539pp.

Hoffman, G. L., Schubert, G. (1984): Some parasites of exotic fishes. pp. 233-261). In Courtenay, W. R., Stauffer, J. R. (eds), Distribution, biology, and management of exotic fishes. The Johns Hopkins University Press. Baltimore and London. 430pp.

Holdich, D. M., Pöckl, M. (2007): Invasive crustaceans in European inland waters. pp. 29-75. In Gherardi, F. (ed) Biological invaders in inland waters: Profiles, distribution, and threats. Springer Netherlands, Dordrecht. 734pp.

Horvat, Š. (1901): Fish and fish culture. Društvo Sv. Jeronima. Zagreb. Tisak Antuna Scholza. 164pp. (in Croatian)

Hulme, P. E., Bacher, S., Kenis, M., Klotz, S., Kühn, I., Minchin, D., Nentwig, W., Olenin, S., Panov, V., Pergl, J., Pyšek, P., Roques, A., Sol, D., Solarz, W., Vilà, M. (2008): Grasping at the routes of biological invasions: a framework for integrating pathways into policy. Journal of Applied Ecology, 45, 2, 403-414.
Ivassik, V. M., Karpenko, I. M. (1967): The change of parasite fauna of cyprinus carpio haematopterus Tem. et Schl. at its introduction into fish ponds of the Ukraine. Parazitologiya, I, 2, 149-150. (in Russian with English abstract)

Ivassik, V., Kulakovska, O. (1968): Novi parasiti na ribnjačarstvima $\mathrm{u}$ vezi sa aklimatizacijom biljojednih riba. Ribarstvo Jugoslavije, 23, 6, 149-150.

Keesing, F., Belden, L. K., Daszak, P., Dobson, A., Harvell, C. D., Holt, R. D., Hudson, P., Jolles, A., Jones, K. E., Mitchell, C. E., Myers, S. S., Bogich, T., Ostfeld, R. S (2010): Impacts of biodiversity on the emergence and transmission of infectious diseases. Nature, 468, 7324, 647-652.

Kelly, D. W., Paterson, R. A., Townsend, C. R., Poulin, R., Tompkins, D. M. (2009): Parasite spillback: a neglected concept in invasion ecology? Ecology, 90, 8, 2047-2056.

Kezić, N., Fijan, N., Kajgana, Lj. (1975): Bothriocephalosis of carp in S. R. Croatia. Veterinarski arhiv 45, 289-291. (in Croatian with English abstract)

Kirjušina, M., Vismanis, K. (2007): Checklist of the parasites of fishes of Latvia. Food and Agriculture Organization of the United Nations. Fisheries Technical Paper. No. 369/3. Rome, FAO. 106pp.

Kolar, C. S., Lodge, D. M. (2001): Progress in invasion biology: predicting invaders. Trends in ecology \& evolution, 16, 4, 199204.

Kuchta, R., Choudhury, A., Scholz, T. (2018): Asian fish tapeworm: the most successful invasive parasite in freshwaters. Trends in parasitology, 34, 6, 511-523.

Kulakovskaya, O. P., Ivasik, V. M. (1967): Parasite fauna of phytophagous fishes in fish ponds of the Lvov Region (The Ukraine). Parazitologiya, I, 4, 325-328. (in Russian with English abstract)

Kurtović, B., Vardić, I., Valić, D., Kapetanović, D., Teskeredžić, Z., Teskeredžić, E. (2009): Health status of chub (Squalius cephalus) in relation to water quality of Sava River. Ribarstvo, 67, 2, 63-75. (in Croatian with English abstract)

Landeka, N., Podnar, M., Jelić, D. J. (2015): New data on the taxonomic status and distribution of Gambusia sp. in Croatia and Bosnia and Herzegovina. Periodicum biologorum, 117, 3, 415-424

Lester, R. J. G., Hayward, C. J. (2006): Phylum Arthropoda. pp. 466-565. In Woo, P. T. K. (ed), Fish diseases and disorders. Vol. 1: Protozoan and Metazoan Infections, $2^{\text {nd }}$ Edition. $C A B$ International. 791pp.

Lom, J., Hoffman, G. L. (1964): Geographic distribution of some species of trichodinids (Ciliata: Peritricha) parasitic on fishes. The Journal of Parasitology, 50, 1, 30-35.

Lymbery, A. J., Morine, M., Kanani, H. G., Beatty, S. J., Morgan, D. L. (2014): Co-invaders: the effects of alien parasites on native hosts. International Journal for Parasitology: Parasites and Wildlife, 3, 2, 171-177.

Maciaszek, R., Sosnowski, W., Wilk, S. (2019): Tropical snail Melanoides tuberculata Müller, 1774 (Thiaridae) found in thermally polluted canal in Central Poland. World Scientific News, 122, 249-254.

Matthews, R. A. (2005): Ichthyophthirius multifiliis Fouquet and ichthyophthiriosis in freshwater teleosts. Advances in parasitology, 59, 159-241.

McGregor, E. A. (1963): Publications on fish parasites and diseases 330 B. C. - A. D. 1923. United States Department of the Interior, Fish and Wildlife Service. Special Scientific Report - Fisheries No. 474. Washington, D. C. pp 84pp.

McVicar, A. H. (2011): Ichthyophonus. pp. 721-747. In Woo, P. T. 
K., Bruno, D. W. (eds), Fish diseases and disorders. Vol.3: viral, bacterial and fungal infections, $2^{\text {nd }}$ Edition. CAB International. 930pp.

Médoc, V., Firmat, C., Sheath, D. J., Pegg, J., Andreou, D., Britton, J. R. (2017): Parasites and biological invasions: predicting ecological alterations at levels from individual hosts to whole networks. pp. 1-54. In Bohan, D. A., Dumbrell, A. J., Massol, F. (eds), Networks of invasion: Empirical evidence and case studies. Advances in Ecological Research, Vol. 57. Academic Press. 297pp.

Mihinjač, T., Sučić, I., Špelić, I., Vucić, M., Ješovnik, A. (2019): Non-native freshwater fishes in Croatia. Ministarstvo zaštite okoliša i energetike, Udruga Hyla. Tiskara Kerschoffset d.o.o. $102 \mathrm{pp}$ (in Croatian)

Minchin, D. (2007): Aquaculture and transport in a changing environment: overlap and links in the spread of alien biota. Marine Pollution Bulletin, 55, 7-9, 302-313.

Mladineo, I., Zrnčić, S., Oraić, D. (2009): Severe helminthic infection of the wild brown trout (Salmo trutta) in Cetina River, Croatia. Bulletin of the European Association of Fish Pathologists, 29, 3, 86.

Molnár, K. (1979): Protozoan parasites of fish species indigenous in Hungary. Parasit. Hung., 12, 5-8.

Molnár, K. (1982): Biology and histopathology of Thelohanellus nikolskii Achmerov, 1955 (myxosporea, myxozoa), a protozoan parasite of the common carp (Cyprinus carpio). Zeitschrift für Parasitenkunde, 68, 3, 269-277.

Molnár, K. (1984a) Parasite range extension by introduction of fish to Hungary. In: Proceedings of the Symposium on Stock Enhancement in the Management of Freshwater Fisheries: Vol. 2: Introductions and Transplantations; 1982 May 31 June 2, Budapest, Hungary. EIFAC Tehnical Paper. Food and Agriculture Organization of the United Nations, Rome, Vol. 42/Suppl./2. p. 534-541.

Molnár, K. (1984b): Occurrence of new monogeneans of fareast origin on the gills of fishes in Hungary. Acta Veterinaria Hungarica, 32, 3-4, 153-157.

Molnár, K. (2009): Data on the parasite fauna of the European common carp Cyprinus carpio carpio and Asian common carp Cyprinus carpio haematopterus support an Asian ancestry of the species. AACL Bioflux, 2, 4, 391-400.

Molnár, K., Kovács-Gayer, E. (1981): Occurrence of two species of Thelohanellus (Myxosporea: Myxozoa) of Far-Eastern origin in common carp populations of the Hungarian fish farms. Parasit. Hung, 14, 51-55.

Molnár, K., Majoros, G., Csaba, G., Székely, C. (2003): Pathology of Atractolytocestus huronensis Anthony, 1958 (Cestoda, Caryophyllaeidae) in Hungarian pond-farmed common carp. Acta Parasitol, 48, 3, 222-228.

Molnár, K., Székely, C., Láng, M. (2019): Field guide to warmwater fish diseases in Central and Eastern Europe, the Caucasus and Central Asia. FAO Fisheries and Aquaculture Circular No.1182. Ankara, FAO. 124 pp.

Mrakovčić, M., Brigić, A., Buj, I., Ćaleta, M., Mustafić, P., Zanella, D. (2006): Red book of freshwater fish of Croatia. Ministarstvo kulture, Državni zavod za zaštitu prirode, Republika Hrvatska. Tisak GIPA d.o.o. 253pp. (in Croatian with English abstract)

Mršić, V. (1934 - 1935): Fish diseases. Ribarski vjesnik, XII, 5-12, 19-21, 33-35, 52-53, 65-69; XIII, 1-12, 2-5, 26-29, 55-60, 8391, 121-131, 145-154, 177-181, 213-216, 257-268, 281-285. (in Croatian)

Musselius, V. A. (1969): Parasites of phytophagous fishes from the Far-East cultivated in ponds of the European part of the
USSR. Parazitologiya, 3, 236-243. (in Russian with English abstract)

Novák, J., Kalous, L., Patoka, J. (2020): Modern ornamental aquaculture in Europe: early history of freshwater fish imports. Reviews in Aquaculture, 12, 4, 1-19.

Nigrelli, R. F., Pokorny, K. S., Ruggieri, G. D. (1976): Notes on Ichthyophthirius multifiliis, a ciliate parasitic on fresh-water fishes, with some remarks on possible physiological races and species. Transactions of the American Microscopical Society, 95, 4, 607-613.

Oidtmann, B. C., Thrush, M. A., Denham, K. L., Peeler, E. J. (2011): International and national biosecurity strategies in aquatic animal health. Aquaculture, 320, 1-2, 22-33.

Oidtmann, B., Johnston, C., Klotins, K., Mylrea, G., Van, P. T., Cabot, S.,Rosado Martin, P., Ababouch, L., Berthe, F. (2013) Assessment of the safety of aquatic animal commodities for international trade: the OIE Aquatic Animal Health Code. Transboundary and emerging diseases, 60, 1, 27-38.

Oikonomou, A., Leprieur, F., Leonardos, I. D. (2014): Biogeography of freshwater fishes of the Balkan Peninsula. Hydrobiologia, 738, 1, 205-220.

Oraić, D., Zrnčić, S. (2005): An overview of health control in Croatian aquaculture. Veterinary research communications, 29, 2, 139-142.

Oraić, D., Zrnčić, S. (2009): Carp diseases - dangers for cage culture. In: Bogut, I, editor, Uzgoj slatkovodne ribe, stanje i perspektive. Zbornik radova. 2009, Zagreb. Hrvatska gospodarska komora. PRINTER GRUPA d.o.o., Sveta Nedjelja. p. 87-94 (in Croatian)

Oraić, D., Zrnčić, S., Lojkić, I., Mladineo, I. (2011): Overview of most important diseases affecting rainbow trout culture in Croatia from 2005. to 2010. In: Mladineo, I, editor,15. EAFP International Conference on Diseases of Fish and Shellfish: Book of abstracts; 2011 Sep 12-16, Split. Split: Dalmacijapapir publishing house p. 307. (poster)

Oros, M., Hanzelová, V., Scholz, T. (2009): Tapeworm Khawia sinensis: review of the introduction and subsequent decline of a pathogen of carp, Cyprinus carpio. Veterinary parasitology, 164, 2-4, 217-222.

Paperna, I. (1991): Diseases caused by parasites in the aquaculture of warm water fish. Annual Review of Fish Diseases, 1, 155-194.

Peeler, E. J., Oidtmann, B. C., Midtlyng, P. J., Miossec, L., Gozlan, R. E. (2011): Non-native aquatic animals introductions have driven disease emergence in Europe. Biological Invasions, 13, 6, 1291-1303.

Peeler, E. J., Reese, R. A., Thrush, M. A. (2015): Animal disease import risk analysis-a review of current methods and practice. Transboundary and emerging diseases, 62, 5, 480490.

Petrinec, Z., Božić, M., Berc, A., Jelić, A. (1999): Most frequent carp (Cyprinus carpio L.) diseases in ponds from 1994 to 1998. Ribarstvo, 57(3), 124-128. (in Croatian with English abstract)

Piria, M., Tomljanović, T., Treer, T., Safner, R., Aničić, I., Matulić, D., Vilizzi, L. (2016): The common carp Cyprinus carpio in Croatia (Danube and Adriatic basins): a historical review. Aquaculture international, 24, 6, 1527-1541.

Piria, M., Simonović, P., Kalogianni, E., Vardakas, L., Koutsikos, N., Zanella, D., Ristovska, M., Apostolou, A., Adrović, A., Mrdak, D., Serhan Tarkan, A., Milošević, D., Zanella, L. N., Bakiu, R., Güler Ekmekçi, F., Povž, M., Korro, K., Nikolić, N., Škrijelj, R., Kostov, V., Gregori, A., Joy, M. K. (2017): Alien freshwater fish species in the Balkans-Vectors and pathways 
of introduction. Fish and fisheries, 19, 1, 138-169.

Pofuk, M., Zanella, D., Piria, M. (2017): An overview of the translocated native and non-native fish species in Croatia: pathways, impacts and management. Management of biological invasions, 8, 3, 425.

Poulin, R., Paterson, R. A., Townsend, C. R., Tompkins, D. M., Kelly, D. W. (2011): Biological invasions and the dynamics of endemic diseases in freshwater ecosystems. Freshwater Biology, 56, 4, 676-688.

Prenter, J., MacNeil, C., Dick, J. T., Dunn, A. M. (2004): Roles of parasites in animal invasions. Trends in ecology \& evolution, 19, 7, 385-390.

Radojević, M., Tomašec, I. (1961): About the problem of fish diseases in our carp ponds. Ribarstvo Jugoslavije, 16, 1, 1115. (in Croatian)

Rahel, F. J. (2000): Homogenization of fish faunas across the United States. Science, 288, 5467, 854-856.

Rowley, J. J., Gleason, F. H., Andreou, D., Marshall, W. L., Lilje, O., Gozlan, R. (2013): Impacts of mesomycetozoean parasites on amphibian and freshwater fish populations. Fungal Biology Reviews, 27, 3-4, 100-111.

Sana, S., Hardouin, E. A., Gozlan, R. E., Ercan, D., Tarkan, A. S., Zhang, T., Andreou, D. (2017): Origin and invasion of the emerging infectious pathogen Spaerothecum destruens: Origin of the emerging infectious pathogen. Emerging microbes \& infections, $6,1,1-8$.

Scholz, T. (1999): Parasites in cultured and feral fish. Veterinary parasitology, 84, 3-4, 317-335.

Scholz, T., Binh, T. T., Dezfuli, B. S. (2011): Khawia japonensis (Cestoda: Caryophyllidea): another invasive parasite of carp, Cyprinus carpio L., imported to Europe. Journal of Fish Diseases, 34, 12, 943-949

Shinn, A. J., Pratoomyot, J., Bron, J., Paladini, G., Brooker, E., Brooker, A. (2015a): Economic impacts of aquatic parasites on global finfish production. Global Aquaculture Advocate, 82, 58-61.

Shinn, A. P., Pratoomyot, J., Bron, J. E., Paladini, G., Brooker, E. E., Brooker, A. J., Timi, J. (2015b): Economic costs of protistan and metazoan parasites to global mariculture. Parasitology, 142, 1, 196.

Simberloff, D., Von Holle, B. (1999): Positive interactions of nonindigenous species: invasional meltdown? Biological invasions, 1, 1, 21-32.

Sim-Smith, C., Diggles, B. (2019): Review of International Aquatic Health Inspection and Surveillance Programmes. MPI Technical Paper No: 2019/05. Ministry for Primary Industries, New Zealand. 153pp.

Soes, D. M., Walker, P. D., Kruijt, D. B. (2010): The Japanese fish louse Argulus japonicus new for The Netherlands. Lauterbornia, 70, 11-17.

Spikmans, F., Lemmers, P., op den Camp, H. J., van Haren, E., Kappen, F., Blaakmeer, A., van der Velde, G., van Langevelde, Leuven, R. S. W. W., van Alen, T. A. (2020): Impact of the invasive alien topmouth gudgeon (Pseudorasbora parva) and its associated parasite Sphaerothecum destruens on native fish species. Biological invasions, 22, 587-601.

Stammer, J. (1959): Beiträge zur Morphologie, biologie und bekämpfung der karpfenläuse. Zeitschrift für Parasitenkunde, 19, 2, 135-208.

Stentiford, G. D., Neil, D. M., Peeler, E. J., Shields, J. D., Small, H. J., Flegel, T. W., Vlak, J. M., Jones, B., Morado, F., Moss, S., Lotz, J., Bartholomay, L., Behringer, D. C., Hauton, C., Lightner, D. V. (2012): Disease will limit future food supply from the global crustacean fishery and aquaculture sectors. Journal of invertebrate pathology, 110, 2, 141-157.

Stentiford, G. D., Sritunyalucksana, K., Flegel, T. W., Williams, B. A., Withyachumnarnkul, B., Itsathitphaisarn, O., Bass, D. (2017): New paradigms to help solve the global aquaculture disease crisis. PLoS pathogens, 13, 2, 1-6.

Stiles, C. W. (1894): Report on a parasitic Protozoan observed on the fish in the aquarium. Bulletin of the United States Fish Commission, 13, 173-190.

Stuart, P., Paredis, L., Henttonen, H., Lawton, C., Torres, C. A. O., Holland, C. V. (2020): The hidden faces of a biological invasion: parasite dynamics of invaders and natives. International Journal for Parasitology, 50, 2, 111-123.

Taraschewski, H. (2006): Hosts and parasites as aliens. Journal of Helminthology, 80, 2, 99-128.

Tavares-Dias, M., Martins, M. L. (2017): An overall estimation of losses caused by diseases in the Brazilian fish farms. Journal of Parasitic Diseases, 41, 4, 913-918.

Thompson, R. C. A., Lymbery, A. J., Smith, A. (2010): Parasites, emerging disease and wildlife conservation. International journal for parasitology, 40, 10, 1163-1170.

Tolley-Jordan, L. R., Chadwick, M. (2012): Centrocestus formosanus Nishigori (Asian gill-trematode). pp. 401-420. In: Francis, R. A. (ed), A Handbook of Global Freshwater Invasive Species. Earthscan. London, New York. 456pp.

Tomašec, I. (1953a): Diseases of freshwater fishes and crustaceans. Jugoslavenska Akademija Znanosti i Umjetnosti. Zagreb. 76pp. (in Croatian)

Tomašec, I. (1953b): Intestinal helmint invasion in fishes. Ribarstvo Jugoslavije, 8, 3, 53-55 (in Croatian)

Tomašec, I. (1966): Fish diseases at the World symposium on warm-water pond fish culture held in Rome in 1966. Ribarstvo Jugoslavije, 21, 5, 103-104. (in Croatian)

Tomašec, I. (1967): Diseases of freshwater fish and crustaceans. pp. 557-595. In: Šatović, F. (ed), Priručnik za slatkovodno ribarstvo. Posebna izdanja, 5. Agronomski glasnik, Zagreb. Savez poljoprivrednih inženjera i tehničara SR Hrvatske. Koprivnička tiskara Koprivnica. 704pp. (in Croatian)

Tomec, M., Hacmanjek, M., Teskeredžić, Z., Teskeredžić, E., ČožRakovac, R. (1995): Water quality and ectoparasite diseases of cyprinidae fish. Ribarstvo, 53, 4, 129-139. (in Croatian with English abstract)

Topić Popović, N., Strunjak-Perović, I., Fonns, A., VilsgaardEspersen, T., Teskeredžić, E. (1999): Pseudorhadinorhynchus salmothymi isolation from brown trout in Krka River (Croatia). Periodicum Biologorum, 101, 3, 273-175.

Topić Popović, N., Hacmanjek, M., Teskeredžić, E. (2001): Health status of rudd (Scardinius erythrophthalmus hesperidicus H.) in Lake Vrana on the Island of Cres, Croatia. Journal of Applied Ichthyology, 17, 1, 43-45.

Torchin, M. E., Lafferty, K. D., Dobson, A. P., McKenzie, V. J., Kuris, A. M. (2003): Introduced species and their missing parasites. Nature, 421, 6923, 628-630.

Torchin, M. E., Mitchell, C. E. (2004): Parasites, pathogens, and invasions by plants and animals. Frontiers in Ecology and the Environment, 2, 4, 183-190.

Trujillo-González, A., Becker, J. A., Hutson, K. S. (2018) Parasite dispersal from the ornamental goldfish trade. pp. 239-281. In: Rollinson, D., Stothard, R. (eds), Advances in parasitology, Vol. 100. Academic Press. 292pp.

Valić, D., Kapetanović, D., Kurtović, B., Teskeredžić, E. (2005): Fish parasites from the river Krka. In: Marguš, D, editor, Simpozij Rijeka Krka i Nacinalni park „Krka“, prirodna i kulturna 
baština, zaštita i održivi razvitak: Zbornik radova; 2005 Oct 5-8, Šibenik. Javna ustanova nacionalni park Krka. p. 10091014.

Valić, D., Vardić Smrzlić, I., Gjurčević, E., Kapetanović, D. (2015): First record of Atractolytocestus huronensis in open water in Croatia. In: Proceedings of the 6th International Scientific Meeting Days of Veterinary Medicine: 2015 Sep. 24-26, Struga, R. Makedonija. Faculty of Veterinary medicine Skpje. p. 65. (poster)

Vardić Smrzlić, I., Valić, D., Kapetanović, D., Zrinka, D., Gjurčević, E., Ćetković, H., Teskeredžić, E. (2013): Molecular characterisation and infection dynamics of Dentitruncus truttae from trout (Salmo trutta and Oncorhynchus mykiss) in Krka River, Croatia. Veterinary Parasitology 197, 3-4, 604-613. Vitousek, P. M., Mooney, H. A., Lubchenco, J., Melillo, J. M.
(1997): Human domination of Earth's ecosystems. Science, 277, 5325, 494-499.

Whittington, R. J., Chong, R. (2007): Global trade in ornamental fish from an Australian perspective: the case for revised import risk analysis and management strategies. Preventive Veterinary Medicine, 81, 1-3, 92-116.

Zadeh, M. J., Peyghan, R., Manavi, S. E. (2014): The detection of Ichthyophonus hoferi in naturally infected fresh water ornamental fishes. Journal of Aquaculture Research and Development, 5, 7, 1-5.

Zrnčić, S., Oraić, D., Šoštarić, B., Ćaleta, M., Bulj, I., Zanella, D. Šurmanović, D. (2009): Occurrence of parasites in Cobitidae from Croatian rivers draining into two different watersheds. Journal of applied ichthyology, 25, 4, 447-450. 